\title{
Uma análise do aspecto regulador do Estado brasileiro à luz do papel das agências reguladoras ${ }^{\star}$
}

\author{
An analysis of the regulatory \\ aspect of the Brazilian State from \\ the perspective of the role of \\ regulatory agencies
}

\author{
Cristina Alves da Silva* \\ Rocco Antonio Rangel Rosso Nelson ${ }^{* * *}$
}

\section{RESUMO}

O presente artigo tem como escopo discutir o surgimento das agências reguladoras diante da evolução do Estado: iniciando no Estado liberal, passando pelo Estado social até chegar ao Estado regulador ou neoliberal. Fez-se um breve histórico do surgimento das primeiras agências

* Artigo recebido em 16 de janeiro de 2013 e aprovado em 26 de abril de 2013.

* Especializanda em direito administrativo pela Universidade Anhanguera-Uniderp. Advogada. Universidade Anhanguera-Uniderp, Mossoró, Rio Grande do Norte, Brasil. E-mail: criistina. silva@gmail.com.

* Especialista em direito e cidadania pela Escola Superior do Ministério Público. Especialista em direito penal e criminologia pela Universidade Potiguar. Mestre em direito constitucional pela Universidade Federal do Rio Grande do Norte (UFRN). Ex-professor do curso de direito da Unifacex. Professor de Direito do Instituto Federal do Rio Grande do Norte (IFRN). Advogado. Instituto Federal do Rio Grande do Norte, Tirol, Rio Grande do Norte, Brasil. E-mail: rocconelson@hotmail.com. 
reguladoras no direito internacional e, ainda, das variadas características desses entes administrativos criados na forma de autarquias em regime especial, dotados de autonomia e poder normativo, e, para tanto, utilizouse uma metodologia de análise qualitativa com métodos de abordagem hipotético-dedutivos de caráter descritivo e analítico. Nesse contexto, buscou-se analisar essa regulação como espécie de intervenção estatal, surgida para ordenar os setores básicos da infraestrutura econômica e, dessa forma, tornam-se as agências reguladoras responsáveis pelo controle, regulamentação e fiscalização de serviços públicos, atividades e bens transferidos ao setor privado.

\section{PALAVRAS-CHAVE}

Agências reguladoras - evolução do Estado - intervenção estatal

\section{ABSTRACT}

This article is scoped to discuss the emergence of regulatory agencies on the evolution of the State: starting in the Liberal State, passing through the Welfare State until you reach the State Regulator or Neoliberal. There was a brief history of the emergence of the first regulatory agencies in international law, and yet, the varied characteristics of these administrative bodies created in the form of local authorities in special regime, endowed with autonomy and legislative powers, and to this end, we used a methodology of qualitative analysis with hypothetical-deductive approach methods of analytical and descriptive character. In this context, we sought to examine this regulation while species of State intervention, which to order the basic sectors of the economic infrastructure, and thus, become the with regulatory agencies, responsible for control, regulation and supervision of public services, activities and assets transferred to the private sector.

\section{KEYWORDS}

Regulatory agencies - evolution of the State - state intervention.

\section{Introdução}

As agências reguladoras demonstram a evidente manifestação de uma escolha política e econômica do Estado, para agir como ente fiscalizador 
das atividades transferidas ao setor privado, corolário do neoliberalismo, contrapondo-se à figura do Estado assistencialista.

O início do Estado regulador foi caracterizado pelo antagonismo que o poder público representava junto à sociedade, que o confundia com o regime absolutista originário do século XVIII, e qualquer influência do Estado no que diz respeito aos interesses individuais era tida como espúria. Era o antigo Estado liberal, influenciado pelo jusnaturalismo e individualismo, não dotado de caráter intervencionista, ou seja, o Estado mínimo. ${ }^{1}$

No Estado liberal acreditava-se que não havia necessidade de regulamentação do mercado pelo poder estatal, de forma que era regido por uma lei natural de oferta e da procura, denominada por Adam Smith de mão invisível do mercado, que regularia o sistema; portanto, um Estado não intervencionista.

Contudo, esse pensamento econômico mostrou-se impossibilitado de solucionar os problemas sociais, e com a crise do liberalismo no final do século XVIII e início do século XIX, houve então a necessidade de o Estado intervir na economia para manter a harmonia do mercado e suprir o déficit na distribuição social, surgindo, dessa forma, o estado do bem-estar social (Welfare State).

Com a implantação do Welfare State, as condições de vida da população se elevaram, a expectativa de vida aumentou; logo, chegou-se ao estágio mais evoluído no processo de aprimoramento da vida comunitária. ${ }^{2}$

Contudo, manter os projetos para satisfação do interesse coletivo demandava recurso que o Estado não mais possuía, houve então um acúmulo de dívidas, de modo que não havia possibilidade de custear nem as despesas essenciais do Estado.

Essa crise fiscal do estado de bem-estar social, no início da década de 1980, conduziu à redução das dimensões do Estado e de sua intervenção direta no âmbito econômico.

Tornou-se necessária a análise de um novo modelo de atuação estatal, que se caracteriza preponderantemente pela utilização da competência normativa para disciplinar a atuação dos particulares. Com o aparecimento de um modelo intervencionista, o Estado permanece presente no domínio

1 CARVAlHO FILHO, José dos Santos. Estado mínimo $\times$ Estado máximo: o dilema. Revista Eletrônica sobre a Reforma do Estado (Rere), Salvador, n. 12, dez./jan./fev. 2008. Disponível em: $<$ www.direitodoestado.com.br/rere.asp>. Acesso em: 10 set. 2011.

2 JUSTEN FILHO, Marçal. O direito das agências reguladores independentes. São Paulo: Dialética, 2002. p. 18. 
econômico; entretanto, ao invés de realizar determinadas atividades, vale-se do instrumento normativo e das suas competências políticas para influenciar os particulares a desenvolver as atividades necessárias à sociedade. Passando os particulares a desenvolver atividades para geração de riquezas e se submetendo aos ditames do poder estatal para funcionamento e desenvolvimento dessas atividades.

Dessa forma, cria o Estado entidades administrativas dotadas de poder regulamentar, para que essas possam normar atividades econômicas e serviços públicos fundamentais, que são, nesse momento, realizados pela iniciativa privada, para garantir o cumprimento da função social dessas atividades e serviços.

E essas entidades administrativas são as chamadas agências reguladoras, criadas na forma de autarquias em regime especial, e responsáveis pelo controle, regulamentação e fiscalização de serviços públicos transferidos pelo Estado ao setor privado.

Além disso, são entidades dotadas de autonomia perante o Poder Executivo e de amplo poder normativo, e, ainda, possuem poder de resolução de conflitos entre as empresas e usuários do serviço prestado, atuam em um setor específico ou geral da economia, e são dotadas de grande conhecimento técnico.

Dessa forma, o ensaio em tela tem como escopo esmiuçar as características desses entes administrativos autônomos do aparato estatal, bem como analisar a evolução estatal e sua influência em face das decisões econômicas e políticas do Estado.

\section{Uma evolução estatal}

Desde a formação do Estado, este passou por várias fases até encontrar a melhor adaptação da sociedade, desde o Estado liberal até o Estado regulador, passando pelo Estado social. Pode-se, claramente, perceber que essas transformações do Estado e sua adequação às necessidades da sociedade são decorrentes de escolhas políticas e econômicas.

Na fase liberal, o Estado se omitia diante das necessidades das coletividades, não havia interferência na economia porque se entendia que o mercado supriria todas as necessidades sociais. Na fase do Estado Social, este assumiu papel de garantidor de todas as necessidades da sociedade, e dessa forma 
houve uma ampliação do rol de despesas do Estado, não havendo mais como manter os custos. ${ }^{3}$

Logo, demonstrando-se falidos esses modelos estatais, apelou-se para uma nova forma de administração estatal, e restou um Estado regulador, denominado por alguns autores como Estado-médio, onde o Estado delega suas funções ao particular e intervém somente como regulador das atividades desenvolvidas pela iniciativa privada, cuidando apenas para evitar a mercantilização dos direitos fundamentais.

É notório que o modelo mais adequado à sociedade moderna é um Estadomédio, aquele que tem a seu cargo as intervenções necessárias e adequadas. Isso porque há um dilema entre a opção de intervenção expressiva do Estado na economia, no Estado social ou Estado-máximo, e a opção da liberdade integral dos segmentos econômicos, no Estado liberal ou Estado-mínimo.

O que parece adaptar-se melhor à contemporaneidade é o Estado-médio: nem o superado liberalismo, nem o fracassado totalitarismo do passado. Logo, cada um assumindo sua posição na sociedade, podem conviver harmoniosamente o Estado e a economia. ${ }^{4}$

Passa-se a analisar, então, cada fase que o Estado assumiu no decorrer dos anos e, ainda, a forma de adequação das funções estatais à sua época.

\subsection{Estado liberal}

O Liberalismo clássico surgiu aproximadamente no século XVIII e início do século XIX, defendido por filósofos tais como Adam Smith (1723-90), John Locke (1632-1704), Kant (1774-1804), Humboldt (1767-1835), John Stuart Mill (1806-73), Benjamin Constant (1767-1830), Alexis de Tocqueville (1805-59) e Montesquieu (1689-1755). Entretanto, iremos nos ater neste trabalho ao liberalismo econômico.

O liberalismo econômico se contrapõe à intervenção política na economia. Os primeiros a se rebelarem contra o controle da economia pelo Estado foram os fisiocratas, cujo lema era "laissez-faire", que significa "deixai fazer, deixai ir, deixai passar".

Sob esse lema, o Estado deveria, somente, garantir a livre concorrência do mercado, não havendo lugar para a intervenção econômica do Estado na sociedade.

\footnotetext{
Ibid., p. 19.

José dos Santos Carvalho Filho, Estado mínimo × Estado máximo, op. cit.
} 
O Estado liberal surge tendo como base a concepção omissiva do Estado e sua função de segurança da manutenção das condições de liberdade, garantindo aos agentes sociais a realização de seus objetivos. ${ }^{5}$

No plano das ideias, podemos dizer que a estrutura que constituiu o Estado liberal, ideológica, política e juridicamente, no fito de propiciar o desenvolvimento e expansão do capitalismo industrial, era, senão perfeito, sem dúvida um grande avanço, em face de uma época de trevas anterior.

No Estado liberal, acreditava-se que não havia necessidade de regulamentação do mercado pelo poder estatal, de forma que era regido por uma lei natural de oferta e da procura, denominada por Adam Smith ${ }^{6}$ de mão invisível do mercado, que regularia o sistema; era, assim, um Estado não intervencionista. E, a essa altura, com a implantação desse modelo estatal liberal, qualquer intervenção do Estado na economia era vista como ilegítima.

Alguns acontecimentos contribuíram para a falência desse modelo estatal, bem como para o surgimento da reação antiliberal. Pode-se citar os acontecimentos da primeira metade do século XX, tais como: Primeira Guerra Mundial (1914-18), Grande Depressão - marcada pela queda vertiginosa da bolsa de valores de Nova York em 1929 - e Segunda Guerra Mundial (193945); esses acontecimentos abalaram a confiança no mercado, e demonstrou-se a necessária atuação do Estado na economia. ${ }^{7}$

Esses acontecimentos ecoam de duas maneiras diferentes: de um lado, criam as bases para o desenvolvimento do Estado intervencionista; e, de outro, propiciam a evolução do fenômeno norte-americano de criação das agências reguladoras, que corresponde ao desenvolvimento da função regulatória do Estado, ocorrida especialmente a partir do "New Deal", programa instaurado por Franklin Roosevelt, na década de 1930, em resposta à crise do Estado Liberal. $^{8}$

Esse modelo de atuação do Estado liberal tornou-se impotente na solução dos problemas econômicos e sociais. Ainda, não trazia benefícios para todas as classes sociais e, sim, promovia uma crescente desigualdade social, desenvolvendo-se, dessa forma, uma reação antiliberal que surge com base

Marçal Justen Filho, O direito das agências reguladores independentes, op. cit., p. 20.

SMITH, Adam. A riqueza das nações: investigação sobre sua natureza e suas causas. Tradução de Luiz João Baraúna. São Paulo: Abril Cultural, 1983. p. 379. (Os economistas).

7 AMARAL, Alexandra da Silva. Princípios estruturantes das agências reguladoras e os mecanismos de controle. Rio de Janeiro: Lumen Juris, 2008. p. 27.

8 Ibid., p. 27. 
nos ataques feitos pelos socialistas, que consideram o liberalismo uma luta inacabável do homem com o meio em que vive.

Entretanto, o mito de um mercado detentor de uma autocorreção foi um ledo engano, pois, na prática, o Estado liberal, solidário com o sistema capitalista, apresentou distorções que colocaram em xeque o próprio Estado.

Esse pensamento econômico liberal apresentou grandes falhas, como a falta de mobilidade dos fatores da economia, a falta de acesso a informações, a concentração econômica, a falta de incentivos na produção de bens coletivos e a estratificação da sociedade, com a formação de uma massa de marginalizados, acarretando um alto índice de desigualdade social.

Então veio a necessidade de o Estado abandonar o seu absenteísmo e intervir na atividade privada, para contornar a crise do liberalismo, vindo a surgir o chamado Estado social, o qual buscou superar o individualismo que perpetrou o liberalismo, em prol da proteção ao social.

Surge então uma nova fase no liberalismo, defendida pelo filósofo e economista inglês John Maynard Keynes (1883-1946), que em 1926 exibe seu ensaio The end of laissez-faire e torna-se inspiração para os países ocidentais redimensionarem a política econômica, propondo uma intervenção maior do Estado nos negócios, com o objetivo de controlar as forças econômicas, criticando o "laissez-faire", lema dos economistas clássicos. ${ }^{9}$

Em sua crítica, Keynes expressa indignação ao modelo liberalista, afirmando que esse modelo econômico-social auxilia os negociantes mais favorecidos em seu crescimento econômico, havendo uma autosseleção dos mais eficientes, e, por sua vez, há a exclusão dos comerciantes menos favorecidos, deixando evidente a cruel luta no mercado pela sobrevivência. ${ }^{10}$

José Eduardo Faria realiza uma síntese do pensamento keynesiano, vindo a aclarar como esse pensamento era ousado e distinto do anterior:

Investindo contra o pensamento econômico convencional, postulando a incapacidade dos mercados para corrigir a subutilização dos recursos produtivos e o desemprego e defendendo a ampliação dos poderes dos bancos centrais com o objetivo de dotá-los de controles mais efetivos sobre as taxas de juros, Keynes argumentava que, no âmbito de

9 LIMA, Michelle Fernandes et al. Liberalismo clássico: origens históricas e fundamentos básicos. Disponível em: <www.histedbr.fae.unicamp.br>. Acesso em: 26 dez. 2011.

10 KEYNES, John Maynard. Economia. Tradução de Mirian Moreira Leite. São Paulo: Ática: 1978. p. 116. (Grandes Cientistas Sociais). 
uma economia capitalista dotada de instituições financeiras capazes de criar poder de compra além das disponibilidades correntes, não seria necessária a existência de uma poupança prévia para que os investimentos se efetivassem. Os investimentos, afirmava ele, dependeriam tão somente das expectativas de lucros dos empresários e da disposição dos gestores das finanças em acreditar na correção daquelas estimativas e adiantar o dinheiro suficiente para aquisição de máquinas, edificação de instalações e contratação de trabalhadores. Deste modo, a análise keynesiana promove uma inversão nas relações de determinação entre poupança e investimento; são as variações no investimento, exprimindo uma maior ou menor confiança dos empresários na consecução de maiores lucros, que provocam variações no nível de renda e de consumo, restando a poupança como um resíduo que se ajusta passivamente. ${ }^{11}$

Esse dirigismo da economia realizado pelo Estado, concebido por Keynes, foi amplamente desenvolvido e executado após a Segunda Guerra Mundial, em que, com a bipolarização do mundo entre americanos e russos, capitalismo e socialismo, dando início à chamada Guerra Fria, gerou a necessidade de se adotar uma política protecionista, por parte dos governos capitalistas, para que os trabalhadores não se simpatizassem com e aderissem às ideologias socialistas, o que de forma evidente comprometeria o domínio da classe burguesa. ${ }^{12}$

Dessa forma, diante da falência do Estado liberal, novos ideais surgiram como caminho para a concepção de um novo modelo estatal, o denominado estado de bem-estar social, ${ }^{13}$ que é definido por um Estado garantidor dos direitos sociais indisponíveis ao indivíduo, tais como saúde, educação e previdência. Sob certo ângulo, é cabível a afirmação de que um estado do bem-estar

11 FARIA, José Eduardo. O direito na economia globalizada. 1. ed., 4. tir. São Paulo: Malheiros, 2004. p. 113. Grifos nossos.

12 "Diversos factores explicarian esta tendencia redistributiva que va contra la lógica de la acumulación de capital. El más importante y significativo fue la presencia del comunismo em la Europa del Este y la necessidad de contrarrestar com mejoras materiales las promesas de transformación que los comunistas anunciaban." PERALTA, Antonio Espantaleón. Neoliberalismo, globalización y estado de bienestar. IN: GÓMEZ, Manuel Herrera; REQUENA, Antonio Trinidad (Coord.). Administración pública y Estado de bienestar. Madri: Thopson Civitas, 2006. p. 128.

13 O Estado do bem-estar (Welfare State) ou Estado assistencial pode ser definido, à primeira análise, como Estado que garante "tipos mínimos de renda, alimentação, saúde, habitação, educação, assegurados a todo o cidadão, não como caridade, mas como direito político" (H. L. Wilensky apud BOBBIO, Norberto et al. Dicionário de política. 9. ed. Brasília: Editora UnB, 1997. v. 2. p. 416). 
social trazia consigo uma grande comodidade filosófica: a transplantação da responsabilidade social do indivíduo para o Estado. ${ }^{14}$

\subsection{Estado social}

Com o colapso do Estado liberal fez-se necessário adotar um novo modelo de Estado, um Estado garantidor da proteção da dignidade da pessoa humana, e os valores fundamentais da sociedade passam a ser buscados pela atuação do Estado. Tal ampliação das funções do Estado diminui a liberdade e a autonomia pessoal, havendo uma transferência da responsabilidade do indivíduo para o Estado, surgindo, assim, o estado do bem-estar social ou Welfare State. ${ }^{15}$

Apoiada pelas ideias de Karl Marx (1818-83) e Friedrich Engels (1820-95), surgiu essa nova doutrina da necessidade de intervenção do Estado como forma de proteger o bem comum; era o denominado Estado máximo. ${ }^{16}$

Marx, em O capital, $^{17}$ expressa claramente o pensamento socialista marxista, que critica o sistema de Estado fundamentado no liberalismo e se opunha ao pensamento dos economistas políticos da época, defendendo que o melhor método é aquele que parte do real e do concreto por ser a síntese de múltiplas determinações. No caso da economia política, analisava-se a população, e uma análise assim teria apenas uma visão caótica, visto a diferença entre as classes sociais que o liberalismo trazia. Destarte, o ataque aos ideais liberais foi o alvo das teorias socialistas desenvolvidas nesse período que repudiavam a desigualdade social evidenciada pelo modelo de Estado liberal.

Corroborando os ideais de Marx, Engels acreditava que o Estado era o produto da sociedade em certa fase se desenvolvimento, que passa a existir a partir da luta inconciliável das classes, sendo necessária a sua manifestação para serem sanadas tais contradições. ${ }^{18}$

O assentimento dos ideais socialistas originou o início do Welfare State, que trouxe consigo um nível de aperfeiçoamento na vida social jamais

14 Marçal Justen Filho, O direito das agências reguladores independentes, op. cit., p. 11.

Ibid., p. 11.

José dos Santos Carvalho Filho, Estado mínimo × Estado máximo, op. cit.

17 MARX, Karl. Divisão do trabalho e manufatura. In:___. . capital: crítica da economia política. 11. ed. São Paulo: Bertrand Brasil-Difel, 1987. L. I. v. 1, p. 218.

18 Engels apud ULIÂNOV, Vladimir Ilítch. O Estado e a revolução. Disponível em: <www. culturabrasil.org/oestadoearevolucao.htm>. Acesso em: 27 dez. 2011. 
experimentado anteriormente, em que o Estado cuidava de interesses coletivos como: previdência, saúde, educação etc.

Tem-se com essa política protecionista antissocialismo, implantado entre a década de 1950 até aproximadamente a década de 1980, o que chamamos de "Welfare State" ou Estado assistencialista ou Estado providência. ${ }^{19}$

Ou seja, o Estado interviria ${ }^{20}$ fortemente na economia (temos a criação de empresas públicas e sociedade de economia mista), proporcionando a concretização dos direitos sociais (direitos fundamentais de segunda geração), como o trabalho, a previdência, saúde, dentre outras benesses, à classe trabalhadora, o que, para tanto, levou à necessidade da cobrança de elevados tributos para financiar toda uma burocracia estatal, servindo, assim, como obste ao crescimento do socialismo ${ }^{21}$ no Ocidente.

Em síntese, o Estado do pós-guerra apresentou as seguintes características:

pelo planejamento estatal, pela intervenção governamental, pelas inovações conceituais e pragmáticas em matéria de regulação dos mercados, pela utilização do direito como instrumento de controle, gestão e direção, pela participação direta do setor público como agente financiador, produtor e distribuidor e por políticas sociais formuladas com o objetivo de assegurar patamares mínimos de igualdade, a partir dos quais haveria espaço para uma livre competição. ${ }^{22}$

19 “É o encarregado de assegurar o bem-estar dos cidadãos ou, no dizer de Hugh Dalton, exchanceler do Tesouro inglês, manter a vida social segura e ordenada e fazer que essa vida, segura e ordenada seja mais digna de ser vivida, desde o ponto de vista econômico ao não econômico. Na realização desse ideário o Estado se fará presente na proteção da iniciativa privada ou diretamente onde esta não puder chegar (intervencionismo). Estará atuante onde não se preservar o interesse da coletividade. Sem ser onipotente, estará vigilante no equilíbrio das atividades humanas." (GOMES, Carlos Roberto de Miranda; CASTRO, Adilson Gurgel de. Curso de direito tributário (parte geral e especial). 7. ed. Natal: Nordeste, 2005. p. 27.)

20 Ver a obra de Washington Peluso Albino de Souza, em que comenta a polissemia da palavra intervenção e a necessidade de releitura da mesma perante a Constituição Federal vigente (SOUZA, Washington Peluso Albino de. Teoria da constituição econômica. Belo Horizonte: Del Rey, 2002. p. 387-393, 420-429).

21 Apesar de muitas variantes do socialismo, consegue vislumbrar uma linha de pensamento comum. Bobbio assim elenca as principais características do socialismo: "a) o direito de propriedade seja fortemente limitado; $b$ ) os principais recursos econômicos estejam sob o controle das classes trabalhadoras; $\mathrm{c}$ ) a sua gestão tenha por objetivo promover a igualdade social (e não somente jurídica ou política)". (BOBBIO, Norberto. Liberalismo e democracia. 6. ed. São Paulo: Brasiliense, 1994. p. 100.)

22 José Eduardo Faria, O direito na economia globalizada, op. cit., p. 111. 
Entretanto, a manutenção dos projetos de satisfação do interesse coletivo demandava a existência de recursos de que o Estado não mais dispunha e, além disso, as dívidas foram se acumulando de modo a impedir até mesmo o custeio de despesas essenciais.

Tão somente, pode-se aceitar a diminuição da dimensão do Estado e de suas competências quando comprovada a sua ineficiência em assegurar a supremacia do princípio da dignidade da pessoa humana, o que ocorre no Welfare State, quando o Estado, por não suportar mais as exigências da sociedade, entra em colapso. Destarte, esse foi o cenário que impulsionou a instauração de um novo modelo político, ou seja, um modelo de Estado regulador.

A crise fiscal do Welfare State conduziu à perspectiva de redução das dimensões do Estado e de sua intervenção direta no âmbito econômico.

De tal sorte, tem como fatores dessa crise do Welfare State a elevada carga tributária, a qual só tende a aumentar, em face da manutenção dos direitos sociais, os quais aumentam e evoluem com o passar do tempo.

Além disso, a melhoria significativa nas condições sanitárias e médicas veio por elevar a expectativa ${ }^{23}$ de vida e, consequentemente, o gasto com saúde pública e previdência, com um maior número de aposentados.

Já a Guerra do Vietnã gerou um déficit público imenso nos EUA, o que acarretou uma desvalorização cambial, aumentando a inflação, que, associada à baixa safra de trigo, na antiga União Soviética, contribuiu para essa explosão inflacionária, pois esse gênero alimentício, por ser insumo para vários outros produtos, teve seu preço elevado no mercado internacional.

Somam-se a tudo isso duas crises do petróleo, em 1973 e 1979, com a diminuição das exportações do produto pelos países árabes em face dos conflitos com os judeus e da revolução realizada pelos aiatolás do Irã.

Esses fatores acarretaram a aceleração da inflação, com os desequilíbrios financeiros decorrentes da queda das receitas tributárias e do aumento das despesas públicas, com a elevação das taxas de desemprego e a subsequente ampliação das tensões trabalhistas e das pressões sindicais, com os confrontos

23 "El pacto social entre capital y trabajo ha facilitado durante varias décadas en Europa la paz social en la producción a cambio de mejoras económicas y sociales que han aumentado el nivel de vida de la población en general. Una dinámica que ha ido recortando la acumulación de capital en beneficio de una política redistributiva que sin duda ha nivelado más las rentas entre los que más y los que menos riqueza tienen." (Antonio Espantaleón Peralta, Neoliberalismo, globalización y estado de bienestar, op. cit., p. 128). 
crescentes entre política econômica e políticas sociais, ${ }^{24}$ o que veio por abalar a confiança na política keynesiana, consequentemente comprometendo a legitimidade da atuação interventiva do Estado providencial.

Em síntese, os ciclos de estagnação e prosperidade começaram a ocorrer num ritmo cada vez maior, a ponto de o Estado não mais conseguir acompanhá-los em tempo hábil por meio do seu dirigismo. Ou seja, o Estado social não mais conseguiu tratar os novos problemas, em decorrência das transformações econômicas e internacionais, ou mesmo dos problemas antigos, que pela sua complexidade e especificidade escaparam da moldura da política macroeconômica, exigindo decisões ad hoc, casuísticas. ${ }^{25}$

Esse Estado provedor tornou-se incapaz de gerir o funcionamento global dos sistemas econômicos, tendo as bases de suporte comprometidas:

a) suas estruturas fiscais foram desarticuladas pela transnacionalização dos capitais financeiros; b) seus processos decisórios foram comprometidos em sua unidade e autonomia; c) o controle direto das ações e condutas dos agentes produtivos deu lugar a uma espécie de delegação de autoridade a instâncias mediadoras semipúblicas ou privadas; d) seus mecanismos jurídicos entraram em descompasso com as manifestações reais das novas forças presentes na sociedade. ${ }^{26}$

Nesse processo de desestruturação do Estado provedor abre-se espaço para o crescimento de uma doutrina que busca resgatar o liberalismo, ficando conhecido esse pensamento econômico como neoliberalismo, ${ }^{27}$ o qual teve seus ideais encampados no governo de Pinochet, no Chile, em 1973, de Margaret Thatcher, na Inglaterra, em 1979, e de Ronald Reagan, ${ }^{28}$ nos EUA, em 1980.

24 Ver José Eduardo Faria, O direito na economia globalizada, op. cit., p. 116.

25 Ibid.

26 Ibid.

27 "Modelo inaugurado no início dos anos 80 pelos governantes Margareth Thatcher na Inglaterra e Ronald Reagan nos Estados Unidos (Consenso de Washington), como reação ao estado intervencionista, e consiste numa reconfiguração institucional do capitalismo, caracterizado pelo afastamento do estado em relação à gestão de diversos setores da economia, num retorno aos pressupostos que formaram o Estado Liberal, tendo por escudo uma globalização de políticas, isto é, a formação de blocos econômicos, criando verdadeiras barreiras protecionistas em torno das economias mais fortes, com tendência a privatizações, reformas estruturais e a retomada de investimentos estrangeiros." (GOMES, Carlos Roberto de Miranda. Manual de direito financeiro e finanças. 3. ed. Natal: F3D, 2006. p. 37).

28 "La presidencia de Ronald Reagan y de Mrs. Thatcher marcó el punto de inflexión en la quiebra de la Economía del Bienestar y deI Estado de Bienestar; pilares básicos de la aplicación de las 
Essa doutrina econômica do neoliberalismo é que proclama pelo "enxugamento" do Estado, onde este seria anêmico, o que vem por delinear uma nova configuração estatal, o Estado mínimo.

Um novo Estado, inserido numa era globalizada, em meio de uma perspectiva neoliberal, delineia-se da seguinte maneira:

se afirma a partir da retomada dos fluxos privados de acumulação de capital e é progressivamente marcada pela desregulação dos mercados, pela "financeirização" do capital, pela extinção dos monopólios estatais, pela privatização de empresas públicas, pela desterritorialização da produção e por uma nova divisão social do trabalho..$^{29}$

Na busca do Estado mínimo, os neoliberais perfilaram uma doutrina que pregava, como exposto, a redução dos tributos e a privatização das empresas públicas, promovendo assim a saída do Estado do mercado como produtor e fornecedor de bens e serviços, onde o mesmo desempenharia a função de marco regulador para que o capitalismo não viesse a enveredar nos mesmos erros do liberalismo clássico, promovendo, de tal sorte, a intensificação da concorrência.

Pode-se afirmar que tal doutrina neoliberal teve como marco instituidor, em âmbito global, o chamado "Consenso de Washington", o qual refletiu os principais direcionamentos em matéria de política econômica, monetária, cambial, fiscal e comercial, emanado dos países desenvolvidos e das mais importantes instituições financeiras privadas do mundo.

O "Consenso de Washington" é confluência das bases neoliberais cunhadas das ideias do liberal clássico Friedrich Hayek, ${ }^{30}$ do monetarista

políticas econômicas Keynesianas aparecidas tras la crisis de 1929 y que han sido hegemónicas em el mundo occidental capitalista desde la terminación de la Segunda Guerra Mundial." (Antonio Espantaleón Peralta, Neoliberalismo, globalización y estado de bienestar, op. cit., p. 128).

29 José Eduardo Faria, O direito na economia globalizada, op. cit., p. 111.

30 “(...) Há, em particular, enorme diferença entre criar deliberadamente um sistema no qual a concorrência produza os maiores benefícios possíveis, e aceitar passivamente as instituições tais como elas são. Talvez nada tenha sido mais prejudicial à causa liberal do que a obstinada insistência de alguns liberais em certas regras gerais primitivas, sobretudo o princípio do laissez-faire. Contudo, de certa maneira, essa insistência era necessária e inevitável. Diante dos inumeráveis interesses a demonstrar que certas medidas trariam benefícios óbvios e imediatos a alguns, ao passo que o mal por elas causado era muito mais indireto e difícil de perceber, apenas regras fixas e imutáveis teriam sido eficazes. E como se firmara uma forte convicção de que era imprescindível haver liberdade na área industrial, a tentação de apresentála como uma regra sem exceções foi grande demais para ser evitada. (...) Muitas eram as 
Milton Friedmann e dos teóricos da escola pública James Buchanan e Mancur Olson Jr., e o "acordo" de sua implementação, tendo por participantes o Departamento do Tesouro, o Federal Reserve, o Departamento de Estado dos Estados Unidos, os Ministérios das Finanças dos demais países do Grupo dos Sete e pelos presidentes dos 20 maiores bancos internacionais, como o Fundo Monetário Internacional, o Banco Mundial, e Organização Mundial do Comércio, dentre outros.

Resultado desse "consenso" foi a propositura de 10 reformas básicas, nas quais os Estados deveriam buscar sua incorporação:

1) disciplina fiscal para eliminação do déficit público; 2) mudança das prioridades em relação às despesas públicas, com a superação de subsídios; 3) reforma tributária, mediante a universalização dos contribuintes e o aumento de impostos; 4) adoção de taxas de juros positivas; 5) determinação da taxa de câmbio pelo mercado; 6) liberalização do comércio exterior; 7) extinção de restrições para os investimentos diretos; 8) privatização das empresas públicas; 9) desregulação das atividades produtivas; e 10) ampliação da segurança patrimonial, por meio do fortalecimento do direito à propriedade. ${ }^{31}$

tarefas evidentes, como o aperfeiçoamento do sistema monetário e a prevenção ou o controle do monopólio, e eram ainda mais numerosas as tarefas menores, mas nem por isso menos importantes, em outros campos em que o governo sem dúvida possuía enormes poderes para o bem e para o mal; tudo levava a esperar que, com uma melhor compreensão dos problemas, algum dia teríamos condições de empregar com êxito esses poderes. Mas se o avanço rumo ao que costumamos chamar ação 'positiva' não podia deixar de ser lento, e se, para aperfeiçoar-se de imediato, o liberalismo tinha de valer-se em grande parte do aumento gradual da riqueza trazida pela liberdade, precisaria por outro lado combater constantemente as propostas políticas antiliberais que ameaçavam esse avanço. O liberalismo veio a ser considerado uma filosofia 'negativa' porque não podia oferecer a cada indivíduo mais do que uma participação no progresso comum - progresso cada vez mais considerado natural e inevitável e não mais encarado como decorrente da política de liberdade. Pode-se mesmo dizer que o próprio sucesso do liberalismo tornou-se a causa do seu declínio. (..) Sem dúvida a promessa de maior liberdade tornou-se uma das armas mais eficazes da propaganda socialista, e por certo a convicção de que o socialismo traria a liberdade é autêntica e sincera. Mas essa convicção apenas intensificaria a tragédia se ficasse demonstrado que aquilo que nos prometiam como o Caminho da Liberdade era na realidade o Caminho da Servidão. Foi inquestionavelmente a promessa de maior liberdade que atraiu um número crescente de liberais para o socialismo e tornou-os incapazes de perceber o conflito existente entre os princípios do socialismo e os do liberalismo, permitindo em muitas ocasiões que os socialistas usurpassem o próprio nome do antigo partido da liberdade." (HAYEK, Friedrich von A. O caminho da servidão. Tradução e revisão de Anna Maria Capovilla, José Ítalo Stelle e Liane de Morais Ribeiro. 5. ed. Rio de Janeiro: Instituto Liberal, 1990. p. 43-52).

31 José Eduardo Faria, O direito na economia globalizada, op. cit., p. 165. 
Passou-se a um novo modelo de atuação estatal, que se caracteriza, preponderantemente, pela utilização da competência normativa para disciplinar a atuação dos particulares, ${ }^{32} \mathrm{o}$ denominado Estado regulador.

\subsection{Estado regulador}

Convém conceituar o Estado regulador como uma organização institucional que se relaciona com as concepções do estado de direito, ${ }^{33}$ que é aquele em que o limite e o fundamento da ação estatal se encontram na ordem jurídica e essencialmente na base desta, a Constituição. ${ }^{34}$

Com o Estado legalista, o direito tornou-se fundamento do Estado, dessa forma abandonou-se o direito costumeiro e idealizou-se a ordem jurídica como um arcabouço de normas positivas, e a ideia de direito natural, que por certo lapso temporal foi acolhida como forma de reger a sociedade, servindo como base para o positivamento das normas e respaldo do poder político, tornou-se maneira de contestação: ideologia contraposta às vigências oficiais e às autoridades instituídas. ${ }^{35}$

Com o advento do novo modelo político de organização econômica fundamentado no neoliberalismo, o Estado passa a exercer a regulação, enquanto espécie de intervenção estatal, que se manifesta tanto por poderes e ações com objetivos declaradamente econômicos como por outros com justificativas diversas, mas efeitos econômicos inevitáveis. ${ }^{36}$

Dessa forma, o Estado passa a usar de mecanismos de intervenção para garantir que os direitos coletivos sejam desenvolvidos corretamente pelo setor privado, sem que a sociedade seja prejudicada, já que o Estado delegou suas funções ao particular.

Assumindo esse novo modelo de regulação, o Estado continua dominando economicamente; entretanto, isso ocorre de forma indireta, porque busca a realização de determinados fins através da utilização de instrumentos normativos políticos que influenciam os particulares a atingirem esses fins.

32 JUSTEN FILHO, Marçal. O direito das agências reguladoras independentes. São Paulo: Dialética, 2002. p. 20.

33 Ibid., p. 20.

34 SALDANHA, Nelson. Formação da teoria constitucional. Rio de Janeiro: Renovar, 2000. p. 19.

35 Ibid., p. 25.

36 SUNDFELD, Carlos Ari (Coord.). Introdução às agências reguladoras. In: Direito administrativo econômico. São Paulo: Malheiros, 2006. p. 18. 
Logo, a regulação torna-se uma característica desse novo modelo econômico, onde o Estado não se utiliza das atividades empresariais e sim de instrumentos que regulam essas atividades desenvolvidas pelo setor privado. Assim, a regulação não é própria de certa família jurídica, mas sim de uma opção de política econômica. ${ }^{37}$

A regulação exercida pelo Estado regulador não busca, apenas, impor os interesses conexos ao poder público, e sim organizar harmoniosamente os vários interesses envolvidos, tanto da sociedade como dos investidores e do setor regulado, de forma que há uma ampliação do controle desenvolvido pela administração pública, que busca agir com base nos princípios de eficiência, eficácia, legitimidade e legalidade.

Todavia, para ser possível que essa regulação ocorra de forma satisfatória, se faz necessário que o Estado opte pela criação de entes públicos capazes de regular os setores da economia, e que sejam dotados de especialidade técnica, até porque seria inviável o Estado controlar todos os setores da economia sem conhecê-los tecnicamente; entretanto, o Estado deve manter sua participação no que concerne a educação e seguridade social, evitando, dessa forma, a mercantilização de valores fundamentais, inerentes à pessoa humana.

O modelo regulatório sugere que somente é cabível ao Estado desempenhar atividades diretas nos setores em que a iniciativa privada pode colocar em risco os valores coletivos ou, ainda, a atuação do particular for insuficiente para realizar o serviço de forma satisfatória.

Destarte, o Estado cria políticas públicas como forma de incentivar os particulares a aplicarem os seus esforços e recursos para desenvolver atividades necessárias ao desenvolvimento econômico e social.

No Brasil, a implantação de um Estado regulador começou há aproximadamente 15 anos, e muitas disputas vêm se verificando ao longo desse período, especialmente em virtude da ausência de uma disciplina normativa mais sistematizada, o que, sob certo ângulo, se utilizar da regulação consiste no emprego intensificado das competências de poder de polícia. ${ }^{38}$ Essa ausência de disciplinas normativas começou a se alterar, o que se evidenciou com a edição da Lei no $11.445 / 2007$; $^{39}$ tal diploma veiculou normas sobre o

37 Ibid., p. 23.

38 JUSTEN FILHO, Marçal. Curso de direito administrativo. São Paulo: Saraiva, 2010. p. 659.

39 Lei no 11.445, de 5 de janeiro de 2007 - Estabelece diretrizes nacionais para o saneamento básico; altera as Leis $\mathrm{n}^{\text {os }}$ 6.766, de 19 de dezembro de 1979, 8.036, de 11 de maio de 1990, 8.666, de 21 de junho de 1993, 8.987, de 13 de fevereiro de 1995; revoga a Lei no 6.528, de 11 de maio de 1978; e dá outras providências. 
saneamento básico e contém regras explícitas sobre a atividade regulatória setorial.

Para que se possa estabelecer um modelo de Estado regulador fez-se necessário haver uma fragmentação das competências normativas e decisórias do Estado. Logo, é imprescindível a atribuição de competência regulatória a entidades administrativas dotadas de autonomia ante o poder político, as conhecidas agências reguladoras, encarregadas da gestão setorial.

\section{Agências reguladoras}

As agências reguladoras formam, hoje, um conjunto de estruturas originais dentro do aparelho do Estado contemporâneo. Sua criação ocorre em resposta a exigências novas e atesta a insuficiência das estruturas tradicionais para responder aos problemas das sociedades complexas e evolutivas.

Isso porque o Estado não possui mecanismos suficientes para suprir todas as necessidades da coletividade, de forma a garantir que os direitos fundamentais sejam assegurados na sua integralidade. ${ }^{40}$

São entidades administrativas integrantes da administração indireta, dotadas de personalidade jurídica de direito público, e são criadas na forma de autarquias em regime especial.

Não há empecilhos da norma constitucional para a lei criar e instituir agências reguladoras e outorgando a elas forma autárquica e as incluir no âmbito do Poder Executivo, de modo que não há que se falar em inconstitucionalidade desses entes administrativos.

Consistem, ainda, em entidades administrativas dotadas de competência regulatória no setor em que atuam, de forma que podem editar normas abstratas infralegais, e ainda possuem poder decisório para dirimir conflitos entre os particulares. Assim, as decisões tomadas por esses entes administrativos são vinculantes para os diversos setores, e podem passar por revisão jurisdicional, porque os seus atos são passíveis de revisão pelo Poder Judiciário, no que se aplica aos atos administrativos.

Para entender melhor a estrutura desses entes administrativos, faz-se necessário esmiuçar suas características, bem como fazer breve histórico de seu surgimento e importância no aparato da administração.

40 Alexandra da Silva Amaral, Princípios estruturantes das agências reguladoras e os mecanismos de controle, op. cit., p. 27. 


\subsection{Breve histórico}

As revoluções liberais do século XVIII refletiram de formas antagônicas na França e nos Estados Unidos; enquanto no primeiro houve desconfianças para com os juízes atuantes, criando uma justiça especializada para a administração pública, nos Estados Unidos, houve um fortalecimento do Poder Judiciário e Legislativo, e desconfiança em relação ao Poder Executivo. ${ }^{41}$ Assim, diante da necessidade de atuação do Estado nas áreas sociais e econômicas, surge o direito administrativo, e com ele as agências reguladoras. É comum dizer que o direito administrativo norte-americano é o "direito das agências". ${ }^{42}$

Nos Estados Unidos utilizou-se do modelo das agências reguladoras como forma de intervenção estatal na ordem econômica e social, como forma de corrigir as falhas do mercado, o que ocorreu ainda no século XIX.

Evidenciou-se, ainda mais, a necessidade de intervenção do Estado por meio da implantação do modelo de agências reguladoras diante da Grande Depressão, em 1929, que teve como uma das causas a quebra da Bolsa de Nova York, e naquele momento foi possível perceber que o mercado não possuía a capacidade de se reerguer sem a intervenção reguladora do Estado.

Logo, o Estado implantou o New Deal, uma série de programas intervencionistas com o escopo de recuperar e reformar a economia norte-americana, e auxiliar aos lesados com a Grande Depressão. Entre esses programas estavam o investimento em obras públicas, destruição de estoques agrícolas, controle sobre o preço e a produção e, ainda, diminuição da jornada de trabalho; portanto, torna-se crescente a implementação das agências reguladoras.

A partir da década de 1970, há um processo nos Estados Unidos de desregulação da economia, diminuindo o poder público as restrições impostas aos setores econômicos e, consequentemente, a redução da intervenção das agências reguladoras sobre a iniciativa privada. E a partir de críticas surgidas em desfavor das agências reguladoras e sua adequação ao princípio da tripartição de poderes, ocorre uma ampliação do controle do Poder Judiciário, que começa a avaliar a legalidade e a razoabilidade das decisões tomadas pelas agências reguladoras.

41 OLIVEIRA, Rafael Carvalho Rezende. O modelo norte-americano das agências reguladoras e sua recepção pelo direito brasileiro. Revista Eletrônica sobra a Reforma do Estado (Rere), Salvador, n. 22, jun./jul./ago. 2010. Disponível em: <www.direitodoestado.com/revista/RERE-22JUNHO-2010-RAFAEL-OLIVEIRA.pdf>. Acesso em: 18 jan. 2012.

42 Eloísa Carbonell e José Luis Muga apud DI PIETRO, Maria Sylvia Zanella. Parcerias na administração pública: concessão, permissão, franquia, terceirização, parceria público privada e outras formas. 5. ed. São Paulo: Atlas, 2005. p. 196. 
No Brasil não foi diferente. A partir da década de 1990, começaram a surgir as agências reguladoras inspiradas no modelo norte-americano. Isso porque, diante da ineficiência do intervencionismo do Estado no governo do então presidente Fernando Henrique Cardoso, houve um fortalecimento da política liberalizante da economia. Assim, buscou-se diminuir a participação do Estado e um aumento nas atividades desenvolvidas pelos particulares, delegando o Estado algumas de suas funções à iniciativa privada, sem, contudo, voltar ao Estado liberal, passando o Estado somente a exercer função reguladora sobre as atividades desenvolvidas.

Dessa forma, com o processo de desestatização atingindo o setor de serviços estatais, surgem as agências reguladoras. Entretanto, a venda das empresas estatais prestadoras de serviços trazia consigo o risco de o Estado perder totalmente o poder de influir em sua prestação e de controlar a estrutura empresarial.

Tanto quanto o sistema financeiro, sistemas como o elétrico ou de telecomunicações demandam autoridades fortes que os monitorem todo o tempo, porque são serviços fundamentais ao país, e seu colapso seria um verdadeiro desastre econômico. Além disso, nesses campos se exerce um extraordinário poder econômico e o Estado não pode ficar indiferente à concentração empresarial excessiva ou fechar os olhos para as práticas anticoncorrenciais. ${ }^{43}$

Como consequência das mudanças na economia do país, fez-se necessário a ocorrência de alterações substanciais no sistema legislativo, principalmente no que concerne à abertura ao capital estrangeiro na Constituição de $1988,{ }^{44}$ atenuação dos monopólios estatais, ${ }^{45}$ e instituição do Programa Nacional de

43 Carlos Ari Sundfeld, Introdução às agências reguladoras, 2006, op. cit., p. 34.

44 Emenda Constitucional no 06/1995 que suprimiu o art. 171 da Constituição de 1988, que conceituava a empresa brasileira e admitia a outorga de benefícios especiais e preferenciais, e, ainda, alterou a redação do art. 176, $§ 1$ o, permitindo a pesquisa e lavra de recursos minerais e o aproveitamento das potências de energia elétrica, concedidos e autorizados para empresas constituídas por leis nacionais, sem a exigência de capital nacional; Emenda Constitucional no 07/1995 que alterou o art. 178 da Constituição de 1988; Emenda Constitucional nº 36/2002 que alterou o art. 178 da Constituição de 1988, passando a admitir participação do capital estrangeiro, no limite de até $30 \%$, nas empresas jornalísticas e de radiofusão.

45 Emenda Constitucional no 05/1995 que alterou o art. 25, §2º , da Constituição de 1988, permitindo que os Estados-membros concedam às empresas privadas a exploração de serviços público locais de gás canalizado; Emenda Constitucional no 08/1995, alterou o art. 21, XI, da Constituição de 1988, permitindo a delegação de serviços de telecomunicações as empresas privadas, prevendo ainda a criação de um órgão regulador; Emenda Constitucional nº 09/1995, alterou o art. 177, §1º , da Constituição de 1988, autorizando contratação pela União de empresas estatais e privadas para execução de diversas atividades ligadas à exploração de petróleo. 
Desestatização (PND). ${ }^{46}$ Assim, após modificações substanciais no aparato legislativo, optou-se por instituir as agências reguladoras como novo modelo de atuação do Estado regulador, ora interventivo.

Todavia, desde que foi outorgada, a Constituição Federal de 1988 evidenciava que o Estado deveria exercer as funções de fiscalização, incentivo e planejamento, atuando como agente normativo e regulador da atividade econômica, de forma determinante para o setor público e indicativo para o setor privado, como se observa nas linhas do art. 174, da Constituição Federal. ${ }^{47}$ E, posteriormente, no ano de 1995, com a instituição das Emendas Constitucionais $\mathrm{n}^{\circ} 8$ e 9, foi prevista a criação de órgãos reguladores específicos para os setores de petróleo ${ }^{48}$ e telecomunicação. ${ }^{49}$

Assim, a Constituição não optou ou exigiu a criação das agências reguladoras, mas deixou essa opção para o legislador que optou pela utilização do modelo norte-americano; evidenciou-se, então, a partir da década de 1990, um processo de "agencificação", 50 que seria a outorga da função regulatória do Estado para as agências reguladoras. Assim, ainda no governo do então presidente Fernando Henrique Cardoso, houve a criação das agências reguladoras: Lei no 9.427/1997 (Aneel); Lei no 9.472/1997 (Anatel); Lei no 9.478/1997 (ANP); Lei no 9.782/1999 (Anvisa); Lei no 9.961/2000 (ANS); Lei no 9.984/2000

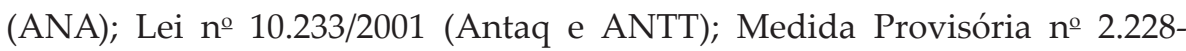
1/2001 e Lei no 10.454/2002 (Ancine); como forma de o Estado tentar suprir as necessidades sociais e econômicas, diante do seu atual sistema de intervenção falido.

46 Programa Nacional de Desestatização (PND) pela Lei no 8.031/1990, substituída mais tarde pela Lei no 9.491/1997.

47 Art. 174. Como agente normativo e regulador da atividade econômica, o Estado exercerá, na forma da lei, as funções de fiscalização, incentivo e planejamento, sendo este determinante para o setor público e indicativo para o setor privado.

48 Art. 21. Compete à União: (...) XI - explorar, diretamente ou mediante autorização, concessão ou permissão, os serviços de telecomunicações, nos termos da lei, que disporá sobre a organização dos serviços, a criação de um órgão regulador e outros aspectos institucionais; (Redação dada pela Emenda Constitucional no 8, de 15/08/95:)

49 Art. 177. Constituem monopólio da União: (...) I - a pesquisa e a lavra das jazidas de petróleo e gás natural e outros hidrocarbonetos fluidos; II - a refinação do petróleo nacional ou estrangeiro; III - a importação e exportação dos produtos e derivados básicos resultantes das atividades previstas nos incisos anteriores; IV - o transporte marítimo do petróleo bruto de origem nacional ou de derivados básicos de petróleo produzidos no País, bem assim o transporte, por meio de conduto, de petróleo bruto, seus derivados e gás natural de qualquer origem;

\$1 1 A União poderá contratar com empresas estatais ou privadas a realização das atividades previstas nos incisos I a IV deste artigo observadas as condições estabelecidas em lei.

${ }_{2} 2^{\circ} \mathrm{A}$ lei a que se refere o $\$ 1^{\circ}$ disporá sobre: (...) III - a estrutura e atribuições do órgão regulador do monopólio da União.

50 DI PIETRO, Maria Sylvia Zanella. Direito administrativo. 19. ed. São Paulo: Atlas, 2006. p. 54. 


\subsection{Natureza jurídica e caracteristicas}

As agências reguladoras são pessoas jurídicas de direito público, classificadas como autarquias em regime especial. Tal classificação é de notória importância para o desenvolvimento das suas funções; isso porque, ao serem criadas na forma de autarquias, são dotadas de autonomia em face dos entes políticos e, assim, não há interferência do Estado no desempenho das atividades com interferência no domínio econômico e fiscalização de prestação dos serviços públicos por parte das agências.

Por possuírem natureza autárquica, as agências reguladoras estão sujeitas ao disposto no art. 37, XIX,11 da Constituição Federal de 1988, ou seja, necessitam de lei específica que as instituam e as extingam. E, ainda, por serem criadas na forma especial, são dotadas de maior estabilidade e autonomia administrativa em razão do seu ente criador, o que as distingue das tradicionais autarquias.

Outra demonstração dessa especialidade é no que concerne à investidura de seus dirigentes, que são nomeados pelo presidente da República, mas distinguindo-se das demais autarquias, essa nomeação vai depender de prévia aprovação do Senado Federal, conforme previsto nos art. 84, XIV, ${ }^{52}$ e 52, III, f, ${ }^{53}$ da Constituição Federal de 1988, combinados com o art. 5o, da Lei no 9.986/2000, ${ }^{54}$ recebendo, por isso, a terminologia de investidura especial.

51 Art. 37. A administração pública direta e indireta de qualquer dos Poderes da União, dos Estados, do Distrito Federal e dos Municípios obedecerá aos princípios de legalidade, impessoalidade, moralidade, publicidade e eficiência e, também, ao seguinte: (...) XIX - somente por lei específica poderá ser criada autarquia e autorizada a instituição de empresa pública, de sociedade de economia mista e de fundação, cabendo à lei complementar, neste último caso, definir as áreas de sua atuação; (Redação dada pela Emenda Constitucional no 19, de 1998).

52 Art. 84. Compete privativamente ao Presidente da República: (...) XIV - nomear, após aprovação pelo Senado Federal, os Ministros do Supremo Tribunal Federal e dos Tribunais Superiores, os Governadores de Territórios, o Procurador-Geral da República, o presidente e os diretores do banco central e outros servidores, quando determinado em lei;

53 Art. 52. Compete privativamente ao Senado Federal: (...) III - aprovar previamente, por voto secreto, após arguição pública, a escolha de: (...) f) titulares de outros cargos que a lei determinar;

54 Lei no 9.986, de 18 de julho de 2000, que dispõe sobre a gestão de recursos humanos das Agências Reguladoras e dá outras providências. (...)Art. 5 o O Presidente ou o Diretor-Geral ou o Diretor-Presidente (CD I) e os demais membros do Conselho Diretor ou da Diretoria (CD II) serão brasileiros, de reputação ilibada, formação universitária e elevado conceito no campo de especialidade dos cargos para os quais serão nomeados, devendo ser escolhidos pelo Presidente da República e por ele nomeados, após aprovação pelo Senado Federal, nos termos da alínea f do inciso III do art. 52 da Constituição Federal. Parágrafo único. O Presidente ou o Diretor-Geral ou o Diretor-Presidente será nomeado pelo Presidente da República dentre os integrantes do Conselho Diretor ou da Diretoria, respectivamente, e investido na função pelo prazo fixado no ato de nomeação. 
Além disso, os dirigentes têm mandato por prazo certo, fixado no ato da nomeação, e a duração não deve ultrapassar a da legislatura do presidente. $\mathrm{E}$, ainda no que diz respeito ao mandato dos dirigentes, há o que a doutrina nomeia de quarentena, que ocorre quando, terminado o mandato, o ex-dirigente é impedido por quatro meses de exercer qualquer atividade ou prestação de serviço no setor regulado pela agência, conforme dispõe o art. $8^{\circ}$ da lei supracitada. ${ }^{55}$

Ainda, os conselheiros e os diretores somente perderão o mandato em caso de renúncia, de condenação judicial transitada em julgado ou de processo administrativo disciplinar, salvo se a lei que instituir a agência reguladora criar outras condições. ${ }^{56}$ E sobre a organização dos demais cargos e carreiras, tem-se a Lei no $10.871 / 2004,{ }^{57}$ que dispõe sobre a criação de carreiras e organização de cargos efetivos das autarquias especiais, denominadas agências reguladoras, definindo o regime estatutário para os agentes, e sobre outras regras.

Outro item de fundamental importância na garantia da autonomia das agências reguladoras é a independência financeira em relação ao erário público, o que ocorre mediante a arrecadação de uma taxa de regulação devida pela concessionária diretamente à agência do setor regulado, taxa com relação direta em razão do proveito financeiro obtido com a concessão, e, dessa forma, a agência não depende de verbas orçamentárias para seu custeio.

Essa taxa de regulação tem natureza contratual, com pagamento contratualmente estipulado, pois é do contrato de concessão de serviços firmado entre o poder concedente e a concessionária que se origina a cobrança, que é fixada como forma de contrapartida para contratação da concessão, assegurando a segurança jurídica dos investimentos. ${ }^{58}$

Entre as principais características das agências reguladoras, pode-se citar o poder normativo concedido a essas autarquias, que mediante esse poder de normar podem editar normas abstratas infralegais de cunho legislativo, como

55 Art. 8o da Lei ํㅗ 9.986/2000, diz que o ex-dirigente fica impedido para o exercício de atividades ou de prestar qualquer serviço no setor regulado pela respectiva agência, por um período de quatro meses, contados da exoneração ou do término do seu mandato.

56 Art. 9o da Lei nº 9.986/2000, dispõe que os conselheiros e os diretores somente perderão o mandato em caso de renúncia, de condenação judicial transitada em julgado ou de processo administrativo disciplinar. Parágrafo único. A lei de criação da Agência poderá prever outras condições para a perda do mandato.

57 Lei no 10.871 , de 20 de maio de 2004, dispõe sobre a criação de carreiras e organização de cargos efetivos das autarquias especiais denominadas Agências Reguladoras, e dá outras providências.

58 CARVALHO, Cristiano Martins. Agências reguladoras. Jus Navegandi, out. 2001. Disponível em: <jus.com.br/revista/texto/2654/agencias-reguladoras>. Acesso em: 19 jan. 2012. 
forma de regulamentar o setor a ser regulado; pode-se dizer que seria uma delegação legislativa.

Há certa controvérsia na doutrina acerca dessa nomenclatura, e os autores avessos a essa ideia justificam que, em função de a natureza desse instituto ser imune ao controle político, somente poderiam as agências emitir normas acerca de matérias de suas competências a partir de uma teoria sobre os regulamentos autônomos brasileiros. ${ }^{59}$

Outros doutrinadores consideram autênticas as delegações de poder legislativo às agências, porquanto pautadas no imperativo de exercício de uma discricionariedade técnica, que se funda em motivos de cunhos científicos e tecnológicos que tornam essa alternativa tecnicamente a mais viável ou a única adequada, ${ }^{60}$ até porque a criação de agências reguladoras como forma de descentralização da administração e com o escopo de obter um maior controle dos serviços prestados exige todo um aparato de conhecimentos técnicos do setor regulado.

Diante disso, válido é o entendimento de que a atribuição de poder normativo às agências reguladoras não exclui o poder de legislar, entretanto, significa o alargamento do desempenho da função normativa do Estado. Destarte, o poder normativo atribuído às agências reguladoras é o que lhe torna peculiar e as diferencia dos papéis clássicos do Executivo, de forma que excluir sua incidência seria obstruir sua própria essência. Necessário, aqui, a ênfase de que seu exercício depende de limites conferidos pela sua lei criadora, o que aparta o argumento de que se estaria diante de regulamentos autônomos. ${ }^{61}$

Também é válido ressaltar que a função normativa da agência reguladora é tão somente técnica e direcionada ao setor regulado, o que requer a edição de normas por agentes especializados. Vale ressaltar que a edição dessas normas deve observar a participação da sociedade e do setor regulado, evitando a criação de um sistema repleto de normas tecnocráticas, que desvalorizam os valores humanos e se atêm a mera racionalização.

Tal juízo seria incompatível com o atual estágio do direito administrativo que acompanhou a evolução do Estado e da sociedade, que acrescentou-se um caráter valorativo, tornando-se necessário a justificação de suas decisões

59 CUÉLLAR, Leila. As agências reguladoras e seu poder normativo. São Paulo: Dialética, 2001. p. 142.

60 SOUTO, Marcos Juruena Villela. Direito administrativo regulatório. Rio de Janeiro: Lumen Juris, 2002. p. 50.

61 Alexandra da Silva Amaral, Princípios estruturantes das agências reguladoras e os mecanismos de controle, op. cit. 
publicamente, respeitando o princípio da publicidade de suas decisões, disposto no art. 37, caput $^{62}$ da Constituição Federal de 1988.

Além disso, as normas reguladoras editadas por essas autarquias devem obedecer a processo argumentativo, garantindo sua legitimidade e assegurando que os interesses da coletividade sejam assegurados, e, ainda, se necessário a legitimidade formal, ausentes a representação democrática, observar-se-á o princípio da participação, garantindo legitimidade substancial.

Ulterior particularidade das agências reguladoras é certa independência conferida a esses entes administrativos, sendo dotados de função judificativa, que nada mais é do que o poder de solucionar conflitos de interesses, decidindo administrativamente esses conflitos entre os delegatários, o poder concedente, a própria agência e os usuários dos serviços prestados. No caso dos serviços públicos podemos citar a Lei nº 8.987/1995, ${ }^{63}$ e, ainda, as leis específicas instituidoras dessas autarquias preveem sua competência para a tomada de decisões, como é o caso da Lei no 9.427/1996, ${ }^{64}$ instituidora da Agência Nacional de Energia Elétrica (Aneel), que no art. 3, V, ${ }^{65}$ atribui competência a esta para dirimir, no âmbito administrativo, as divergências entre concessionárias, permissionárias, autorizadas, produtores independentes e autoprodutores, bem como entre esses agentes e seus consumidores, bem como as leis instituidoras das demais agências reguladoras que preveem tal competência para solucionarem conflitos.

Entretanto, essa independência deve ser compatível com o regime constitucional brasileiro, e de modo algum pode-se afastar o princípio básico determinante em nosso sistema político democrático, predito pelo art. 5o, $\mathrm{XXXV} .{ }^{66}$

62 Art. 37. A administração pública direta e indireta de qualquer dos Poderes da União, dos Estados, do Distrito Federal e dos Municípios obedecerá aos princípios de legalidade, impessoalidade, moralidade, publicidade e eficiência e, também, ao seguinte.

63 Lei no 8.987, de 12 de fevereiro de 1995, que dispõe sobre o regime de concessão e permissão da prestação de serviços públicos previsto no art. 175 da Constituição Federal, e dá outras providências.

64 Lei no 9.427, de 26 de dezembro de 1996, que Institui a Agência Nacional de Energia Elétrica - ANEEL, disciplina o regime das concessões de serviços públicos de energia elétrica e dá outras providências.

65 Art. 3ำ Além das atribuições previstas nos incisos II, III, V, VI, VII, X, XI e XII do art. 29 e no art. 30 da Lei no 8.987, de 13 de fevereiro de 1995, de outras incumbências expressamente previstas em lei e observado o disposto no $\S 1$ o , compete à ANEEL: (...) V - dirimir, no âmbito administrativo, as divergências entre concessionárias, permissionárias, autorizadas, produtores independentes e autoprodutores, bem como entre esses agentes e seus consumidores;

${ }_{66}$ Art. 5ำ Todos são iguais perante a lei, sem distinção de qualquer natureza, garantindo-se aos brasileiros e aos estrangeiros residentes no País a inviolabilidade do direito à vida, à liberdade, à igualdade, à segurança e à propriedade, nos termos seguintes: (...) XXXV - a lei não excluirá da apreciação do Poder Judiciário lesão ou ameaça a direito. 
Assim, em relação ao Poder Judiciário, a suposta independência não existe, tendo em vista o sistema de unidade de jurisdição, garantido pelo artigo supracitado da Constituição Federal de 1988.

Logo, o fato de ser a última instância administrativa, a decisão tomada por ela não deve ser submetida a controle através de recurso hierárquico impróprio, e por ser evidentemente técnica não pode sofrer intromissão política, e, com obviedade, não obsta recurso ao Judiciário para revisão dessas decisões no que se aplica aos atos administrativos. ${ }^{67}$

Ademais, em razão da necessidade da coexistência de todos os interesses presentes, surge a exigência da imparcialidade na função reguladora no sentido da neutralidade político-partidária.

Isso porque, enquanto no modelo unificado bastava a democracia formal representativa para legitimar as decisões, no modelo bipartido passa a existir uma duplicidade de fontes legitimatórias, sendo a democracia formal e, em acréscimo, a democracia substantiva. A nova e especial legitimidade administrativa dos dirigentes das agências reguladoras deve se fundamentar nas premissas da democracia substancial, pela legitimidade corrente, permanentemente aferida na eficiência de seu desempenho, inclusive por meio dos mecanismos de participação democrática. ${ }^{6}$

O exercício politicamente neutro exigido pela função de regulação deve ser entendido com conteúdo restrito aos aspectos de independência dos gestores (nomeação, mandatos a termo, estabilidade, sem ingerência do Executivo); independência técnica dos gestores (para decisões politicamente neutras); independência normativa (regulação como principal instrumento de ação setorial); independência gerencial, financeira e orçamentária (afastar a ingerência da administração indireta). Logo, não sendo uma nova função política, mas uma nova função administrativa. ${ }^{69}$

Assim, não se enquadrando como órgãos políticos, as agências reguladoras são entes dotados de funções administrativas e não políticas, atingida, portanto, a legitimação administrativa pela participação democrática e pela eficiência técnica no equacionamento administrativo e na aplicação da solução reguladora específica ao setor.

67 MENDES, Conrado Hubner. Reforma do Estado e agências reguladoras: estabelecendo os parâmetros de discussão. SUNDFELD, Carlos Ari (Coord.). Direito administrativo econômico. São Paulo: Malheiros, 2006. p. 131.

68 NETO, Diogo de Figueiredo Moreira. Direito regulatório: uma alternativa participativa e flexível de relações setoriais complexas no Estado democrático. Rio de Janeiro: Renovar, 2003. p. 157.

69 Ibid., p. 157. 
Pode-se afirmar que as competências das quais as agências reguladoras são dotadas fortalecem o Estado, porque retiram do emaranhado das lutas políticas a regulação de importantes atividades sociais e econômicas, atenuando a concentração de poderes na administração pública, e, assim, alcançam de forma mais satisfatória o objetivo da separação de poderes, que é garantir de forma mais eficaz a segurança jurídica, proteção da coletividade e dos particulares, mantendo a probabilidade da interferência do legislador, seja para alterar o regime jurídico da agência reguladora, ou mesmo para extingui-la. ${ }^{70}$

\subsection{Agências reguladoras no Brasil}

No Brasil, um dos pontos de máxima proeminência da reforma administrativa do Estado consistiu no processo de desestatização ocorrido na década de 1990, em que foram instituídas medidas para distanciar do poder estatal determinadas atividades, que se achava que seriam desempenhadas mais eficientemente pelo setor privado, bem como porque o Estado interventor do atual momento não conseguia desempenhar seu papel de forma hábil. Assim, fazia-se necessário a ocorrência de uma desregulamentação, reduzindo a quantidade de normas limitativas da atividade econômica. ${ }^{71}$

Logo, no Brasil, as agências reguladoras são um instituto bastante recente, surgido a partir de 1996 e fruto do processo de desestatização que se desen-

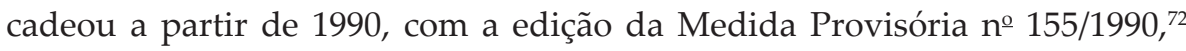
convertida na Lei no 8.031/1990, que estabeleceu o chamado "Plano Brasil Novo", no governo do então presidente Fernando Collor, e posteriormente regulamentada pela Lei no 9.491/1997,73 que disciplina o Plano Nacional de Desestatização, ${ }^{74}$ instituída em governo posterior, o do presidente Fernando Henrique Cardoso.

70 ARAGÃO, Alexandre Santos de. Agências reguladoras e a evolução do direito administrativo econômico. 2. ed. Rio de Janeiro: Forense, 2006. p. 375.

71 José dos Santos Carvalho Filho, Estado mínimo × Estado máximo, op. cit.

72 Medida Provisória 155/90, de 15 de março de 1990, que cria o programa nacional de desestatização, convertida posteriormente na Lei no 8.031 de 12 de abril de 1990 .

73 Lei no 9.491, de 9 de setembro de 1997, que altera procedimentos relativos ao Programa Nacional de Desestatização, revoga a Lei no 8.031, de 12 de abril de 1990, e dá outras providências.

74 AMARAL, Alexandra da Silva Amaral, Princípios estruturantes das agências reguladoras e os mecanismos de controle, op. cit., p.37. 
A primeira autarquia em regime especial a ter recebido o nome de agência reguladora no Brasil foi a Agência Nacional de Energia Elétrica (Aneel), constituída pela Lei no 9.427, de 1996. Em seguida foram estabelecidas igualmente a Agência Nacional de Telecomunicações (Anatel) e a Agência Nacional de Petróleo (ANP), respectivamente pelas Leis no 9.472, de 1997, e no 9.478, de 1997 .

A criação das agências reguladoras não ocorreu de forma eventual. Insere-se num contexto histórico que ajunta algumas circunstâncias, tais como crise absoluta e falha do modelo de Estado interventor, ora prestador de serviços; o desencadeamento de um processo de desestatização, atribuindo a entes econômicos particulares o direito de prestar serviços públicos, por meio de delegação, que até então eram prestados exclusivamente por empresas estatais; e a necessidade de ser conferir segurança e independência aos investimentos estrangeiros. ${ }^{75}$

A Constituição Federal deixou evidente que o setor econômico estaria a cargo da iniciativa privada, conforme se observa no art. $170,{ }^{76}$ reservando ao Estado o papel de agente normativo e regulador da mesma atividade, segundo o art. $174,,^{77}$ a ele só se atribuindo a exploração direta do setor nas situações descritas na forma do art. $173,{ }^{78}$ ou seja, quando necessárias aos imperativos da segurança nacional ou relevante interesse coletivo.

Dessa forma, o Estado atua subsidiariamente no setor econômico, exercendo as funções que não cabem à iniciativa privada como forma de administrar o patrimônio público de forma mais eficiente.

Portanto, ressalta-se que as agências reguladoras surgiram no Brasil por decisão estritamente política, visando um melhor desempenho do papel do Estado, e da divisão de funções nascidas com o princípio da separação de poderes, como forma de fiscalizar e garantir que as atividades desenvolvidas

75 Conrado Hubner Mendes, Reforma do Estado e agências reguladoras: estabelecendo os parâmetros de discussão, op. cit., p. 123.

76 Art. 170. A ordem econômica, fundada na valorização do trabalho humano e na livreiniciativa, tem por fim assegurar a todos existência digna, conforme os ditames da justiça social, observados os seguintes princípios: Parágrafo único. É assegurado a todos o livre exercício de qualquer atividade econômica, independentemente de autorização de órgãos públicos, salvo nos casos previstos em lei.

77 Art. 174. Como agente normativo e regulador da atividade econômica, o Estado exercerá, na forma da lei, as funções de fiscalização, incentivo e planejamento, sendo este determinante para o setor público e indicativo para o setor privado.

78 Art. 173. Ressalvados os casos previstos nesta Constituição, a exploração direta de atividade econômica pelo Estado só será permitida quando necessária aos imperativos da segurança nacional ou a relevante interesse coletivo, conforme definidos em lei. 
pela iniciativa privada obedeçam aos ditames estabelecidos pela sociedade no contexto atual.

\section{Considerações finais}

No dinamismo social que se sucede em volta da globalização, do desenvolvimento tecnológico, bem como do surgimento e desenvolvimento de novos direitos, far-se-á necessária a reestruturação estatal para que se possa gerenciar com eficácia essa mutação, cada vez mais veloz, do corpo social.

Para tanto, a visão estanque da teoria da tripartição dos poderes e o culto à figura da lei, que no Estado Liberal proporcionou a quebra das amarras do absolutismo e a promoção do individualismo, tendo por fito os ideais capitalistas e o apogeu da classe burguesa, não se fazem mais úteis, tornando, na verdade, um obste à atuação do Estado em efetivar os novos anseios da sociedade de massas.

Tem-se a necessidade, em virtude do acima esposado, do atuar estatal de forma mais célere, mais presente, e que consiga se adaptar, em tempo hábil, às mudanças de "tendências", o que se torna perfeitamente viável quando se depende exclusivamente do Poder Legislativo como criador de normas, determinando o atuar dos demais poderes, principalmente do Poder Executivo.

Diante da ineficiência das ideias do Estado liberal, que asseguravam a fantasia de um modelo estatal onde o comércio poderia suprir todas as necessidades sociais sem a interferência do Estado, fez-se necessário o surgimento de um novo modelo de Estado. Passa-se então a adotar os ideários de Estado social, onde o Estado era responsável por suprir todas as necessidades sociais. Entretanto, esse arquétipo de Estado garantidor encharcou os cofres públicos e gerou sua própria falência.

Assim, mostrando-se insuficiente o modelo do Welfare State, o Estado reformulou seu molde administrativo e tornou-se um fiscalizador e regulador da economia, delegando à iniciativa privada funções que lhe eram peculiares. A partir de então, passa a exercer diretamente apenas atividades indelegáveis, quais sejam: aquelas que não são passíveis de comercialização, como saúde e educação, que são inerentes ao próprio ser humano, e que estão amparadas pelo princípio da dignidade da pessoa humana.

Com o fito de executar as diversas funções estatais e concretizar os novos fins agregados às atribuições do Estado, a figura de órgãos auxiliares aos três 
poderes é constante e necessária, o que ensejou o aparecimento das chamadas agências reguladoras.

Neste contexto, a criação das agências reguladoras teve o escopo de permitir que a administração exercesse esse controle em cada setor delegado ao particular, visto a máquina estatal não ter condições de fazê-lo de forma satisfatória. Isto porque essas autarquias são dotadas de poder normativo, podendo, ainda, utilizar-se de sua função judificativa para dirimir conflitos de interesses entre os delegatários, o poder concedente, a própria agência e os usuários dos serviços prestados.

É clarividente que as funções atribuídas às agências reguladoras em nada comprometem a teoria da tripartição dos poderes, como deduzem, a priori, muitos. Pelo contrário, sua legitimidade e vitalidade insurgem exatamente do equilíbrio entre os influxos - pesos e contrapesos - exercidos pelo Poder Executivo, Judiciário e Legislativo em suas interações mútuas.

Além disso, por surgir mediante decisões políticas e para que não sofresse influências do sistema estatal, lhe foi conferida certa independência em relação aos três poderes do Estado: Poder Legislativo, Poder Executivo e Poder Judiciário. Portanto, mesmo estando inserida no seio do Poder Executivo, e integrar a administração indireta, sua independência é nítida em face desse poder, não sofrendo interferências de cunho político.

Saliente-se a necessidade de se afastar como verdade a afirmação de que esses entes administrativos usurpam a função do Poder Legislativo. Ora, evidente é que o poder de normar das agências reguladoras é estritamente técnico e direcionado ao setor regulado, sendo normas de cunho abstrato infralegal, e isso significa que a agência não é investida de competência para editar normas de cunho legislativo.

Em um aspecto macro, abraçar o poder regulamentar, como manifestação da função normativa inerente de um poder uno e indivisível, mitigando a técnica da tripartição dos poderes, possibilita que o Estado seja um "animal, que pode adaptar-se ao meio ambiente", fazendo luzir a efetivação dos direitos fundamentais.

No que concerne ao controle dessas autarquias pelo Judiciário, as mesmas estão a esse Poder submetidas no tocante à revisão de suas decisões, no que cabe à legalidade dos seus atos administrativos.

Dessa forma, é válida e democraticamente legítima a criação de agências reguladoras como forma de fortalecer o controle do Estado em face dos particulares, porque, conforme demonstrado, essas autarquias não usurpam do Estado a sua função, apenas a complementam. 
Por isso, pode-se dizer que foi de muita valia o Estado instituir as agências reguladoras como um mecanismo mais eficiente de controle, ampliando suas funções por meio de um instituto da administração indireta, tonando-o um Estado fiscalizador e regulador dos serviços prestados pelo particular, que, ao exercer as funções que eram típicas do Estado, desonera os cofres públicos, deixando que o Estado somente forneça os serviços não passíveis de comercialização, indispensáveis ao ser humano.

Corteja-se que as figuras das agências reguladoras são fruto de um movimento de retomada da legitimidade, em face da legalidade, contrapondose à fundição da legitimidade na legalidade, ocorrida no Estado Liberal, com o positivismo jurídico. ${ }^{79}$

Por fim, é notório que a criação das agências reguladoras torna o desenvolvimento das funções do Estado mais eficazes, e são mecanismos que auxiliam um melhor desenvolvimento na prestação do serviço pelo setor privado à sociedade, de forma que esses sejam oferecidos de forma mais satisfatória, e dentro dos padrões socialmente exigíveis.

\section{Referências}

AMARAL, Alexandra da Silva. Princípios estruturantes das agências reguladoras e os mecanismos de controle. Rio de Janeiro: Lumen Juris, 2008.

ARAGÃO, Alexandre Santos de. Agências reguladoras e a evolução do direito administrativo econômico. 2. ed. Rio de Janeiro: Forense, 2006.

BOBBIO, Norberto. Dicionário de política. 9. ed. Brasília: Editora UnB, 1997. . Liberalismo e democracia. 6. ed. São Paulo: Brasiliense, 1994.

BONAVIDES, Paulo. Do Estado liberal ao Estado social. 8. ed. São Paulo: Malheiros, 2007.

BRASIL. Constituição da República Federativa do Brasil. Brasília, DF, 5 de outubro de 1988. Disponível em: <www.planalto.gov.br/ccivil_03/Constituicao/ Constitui\%C3\%A7ao.htm>. Acesso em: 23 fev. 2012.

. Lei no 8.031, de 12 de abril de 1990. Disponível em: <www.planalto.gov. br/ccivil_03/leis/L8031.htm>. Acesso em: 23 fev. 2012.

79 BONAVIDES, Paulo. Do Estado liberal ao Estado social. 8. ed. São Paulo: Malheiros, 2007. p. 37. 
. Lei no 8.987, de 12 de fevereiro de 1995. Disponível em: <www.planalto. gov.br/ccivil_03/leis/L8987cons.htm>. Acesso em: 23 fev. 2012.

. Lei no 9.427, de 26 de dezembro de 1996. Disponível em: <www.aneel. gov.br/cedoc/lei19969427.pdf>. Acesso em: 23 fev. 2012.

. Lei no 9.491, de 09 de setembro de 1997. Disponível em: <www.planalto. gov.br/ccivil_03/leis/L9491.htm>. Acesso em: 23 fev. 2012.

. Lei no 9.986, de 18 de julho de 2000. Disponível em:<www.planalto.gov. br/ccivil_03/leis/L9986.htm>. Acesso em: 23 fev. 2012.

. Lei no 10.871, de 20 de maio de 2004. Disponível em: <www.planalto. gov.br/ccivil_03/_ato2004-2006/2004/lei/110.871.htm>. Acesso em: 23 fev. 2012. . Lei no 11.445, de 05 de janeiro de 2007. Disponível em: <www.planalto. gov.br/ccivil_03/_ato2007-2010/2007/lei/111445.htm>. Acesso em: 23 fev. 2012. CARVALHO, Cristiano Martins. Agências Reguladoras. Jus Navegandi, edição de outubro/2001. Disponível em: <http://jus.com.br/revista/texto/2654/ agencias-reguladoras $>$. Acesso em: 19 jan. 2012.

CUÉLLAR, Leila. As agências reguladoras e seu poder normativo. São Paulo: Dialética, 2001.

DALLARI, Dalmo de Abreu. Elementos de teoria geral do estado. 24. ed. São Paulo: Saraiva, 2003.

DI PIETRO, Maria Sylvia Zanella. Direito administrativo. 19. ed. São Paulo: Atlas, 2006.

- Parcerias na administração pública: concessão, permissão, franquia, terceirização, parceria público privada e outras formas. 5. ed. São Paulo: Atlas, 2005.

ENTERRÍA, Eduardo García; FERNÁNDEZ, Tomás-Ramón. Curso de derecho administrativo. Madri: Civitas Ediciones, 2002. v. I.

FARIA, José Eduardo. O direito na economia globalizada. 1. ed., 4. tir. São Paulo: Malheiros, 2004.

FILHO, José dos Santos Carvalho. Estado mínimo × Estado máximo: o dilema. Revista Eletrônica sobre a Reforma do Estado (Rere), Salvador, n. 12, dez./jan./fev. 2008. Disponível em: <www.direitodoestado.com.br/rere.asp >. Acesso em: 10 set. 2011. 
GOMES, Carlos Roberto de Miranda. Manual de direito financeiro e finanças. 3. ed. Natal: F3D, 2006.

; CASTRO, Adilson Gurgel de. Curso de direito tributário (parte geral e especial). 7. ed. Natal: Nordeste, 2005.

HAYEK, Friedrich von A. O caminho da servidão. Tradução e revisão de Anna Maria Capovilla, José Ítalo Stelle e Liane de Morais Ribeiro. 5. ed. Rio de Janeiro: Instituto Liberal, 1990.

JUSTEN FILHO, Marçal. Curso de direito administrativo. São Paulo: Saraiva, 2010.

. O direito das agências reguladoras independentes. São Paulo: Dialética, 2002. KEYNES, John Maynard. Economia. Tradução de Mirian Moreira Leite. São Paulo: Ática: 1978.

LEHFELD, Lucas de Souza. Controles das agências reguladoras. São Paulo: Atlas, 2008.

LIMA, Michelle Fernandes. Liberalismo clássico: origens históricas e fundamentos básicos. Disponível em: <www.histedbr.fae.unicamp.br>. Acesso em: 26 dez. 2011.

MARX, Karl. Divisão do trabalho e manufatura. In: O capital: crítica da economia política. 11. ed. São Paulo: Bertrand Brasil; Difel, 1987.

MENDES, Conrado Hubner. Reforma do Estado e agências reguladoras: estabelecendo os parâmetros de discussão. SUNDFELD, Carlos Ari (Coord.). Direito administrativo econômico. São Paulo: Malheiros, 2006.

OLIVEIRA, Rafael Carvalho Rezende. O modelo norte-americano das agências reguladoras e sua recepção pelo direito brasileiro. Revista Eletrônica sobre a Reforma do Estado (Rere), Salvador, n. 22, jun./jul./ago. 2010. Disponível em: <www.direitodoestado.com/revista/RERE-22-JUNHO-2010-RAFAELOLIVEIRA.pdf $>$. Acesso em: 18 jan. 2012.

PERALTA, Antonio Espantaleón. Neoliberalismo, globalización y estado de bienestar. In: GÓMEZ, Manuel Herrera; REQUENA, Antonio Trinidad (Coord.). Administración pública y Estado de bienestar. Madri: Thopson Civitas, 2006.

SALDANHA, Nelson. Formação da teoria constitucional. Rio de Janeiro: Renovar, 2000. 
SMITH, Adam. A riqueza das nações: investigação sobre sua natureza e suas causas. Tradução de Luiz João Baraúna. São Paulo: Abril Cultural, 1983.

SOUTO, Marcos Juruena Villela. Direito administrativo regulatório. Rio de Janeiro: Lumen Juris, 2002.

SOUZA, Washington Peluso Albino de. Teoria da constituição econômica. Belo Horizonte: Del Rey, 2002.

SUNDFELD, Carlos Ari. Introdução às agências reguladoras. In: (Coord.). Direito administrativo econômico. São Paulo: Malheiros, 2006.

ULIÂNOV, Vladimir Ilítch. O Estado e a revolução. Disponível em: <www. culturabrasil.org/oestadoearevolucao.htm>. Acesso em: 27 dez. 2011. 